\title{
Research on the Promotion of Modern Educational Technology to Logistics Education under the "Internet Plus" Background
}

\author{
Jialin Zhan ${ }^{1, \mathrm{a}^{*}}$ \\ ${ }^{1}$ Nanchang Institute of Sciense \& Technology, Nanchang, China \\ a2903292434@qq.com
}

Keywords: Internet plus; Flipped classroom; Case method; School enterprise interaction; logistics

\begin{abstract}
Internet plus" is a new form of the development of the Internet, is the Internet evolution and its economic and social development of new forms of birth. The traditional form of logistics is "physical distribution" or "goods distribution", and the corresponding traditional logistics teaching mode is also aimed at the traditional logistics mode. This paper mainly studies the promoting role of modern educational technology in logistics teaching mode. The development of adaptation "Internet plus" technology, including the modern education model: This paper focuses on the research of flipping the classroom, case teaching, school enterprise interaction, the project teaching method and game teaching method etc.. To promote the role of different educational methods of logistics education are different, we hope that in the process of research, we found that different promoting effect of different education mode on modern logistics mode of education, improve the teaching quality of logistics education, improve the students' practical ability, teamwork ability, and social integration ability.
\end{abstract}

\section{Introduction}

"Internet plus" means "Internet plus various traditional industries, but it is not a simple sum, but the use of information technology and the Internet platform, so that the Internet and traditional industries depth of integration, create a new developing form[1]. "Internet plus" technology to make people's lives have been greatly convenient, it shortens the distance between people and facilitate the transfer and exchange of goods between people. The modern business model has gradually changed from the traditional business model to the e-commerce model. E-commerce is a general term for all kinds of activities centered on commodity exchange with high speed and low cost[2]. Logistics refers to the maximum to meet customer requirements, with low cost, through storage, handling, packaging, goods or information provided by the origin of goods management and transport goods to the destination of the whole process[3][4]. Modern logistics is the product of economic globalization, and it also promotes economic globalization. Europe, the United States, Japan and other countries have become an important global logistics base, the world's modern logistics industry showed a steady growth[5]. In order to follow the world trend of modern logistics industry, promote the China steady growth of our university education must change the traditional mode of education, in the classroom to make full use of modern educational technology, such as: teaching and game teaching method driven by flipping the classroom, case teaching, school enterprise cooperation projects, promoting Modern Logistics Majors and social integration and the ability to adapt to society, and ultimately promote the development of modern logistics technology China.

\section{The Effect of Turning Classroom on Logistics Education}

This year, the logistics industry has developed rapidly, and the government has paid more and more attention to the logistics industry, which has attracted more and more attention. Therefore, in order to meet the needs of society and enterprises, many colleges and universities have set up logistics management major, which has trained many logistics talents for enterprises and society. Of course, logistics courses are also offered in other similar professions, such as marketing, business 
administration and international economics and trade. There are some theories of logistics, but the logistics is a very practical course, it is mainly about how to improve the efficiency of logistics, with the lowest cost to create the value of customer satisfaction, in the process of flipping the classroom, teachers lead students to carry on the effective design, planning, organization and control of logistics system[6]. Is the current status of logistics education relies on the theory of classroom teaching, teachers focus on textbook knowledge to explain and indoctrination, but ignore the students' practical ability, make the logistics professional students can apply theoretical knowledge to practical operation. In view of this situation, the theory teaching and logistics practice ability are organically combined, and the method of "flipped classroom" is adopted to solve the problem. Fig. 1 is a logistics rollover classroom model.

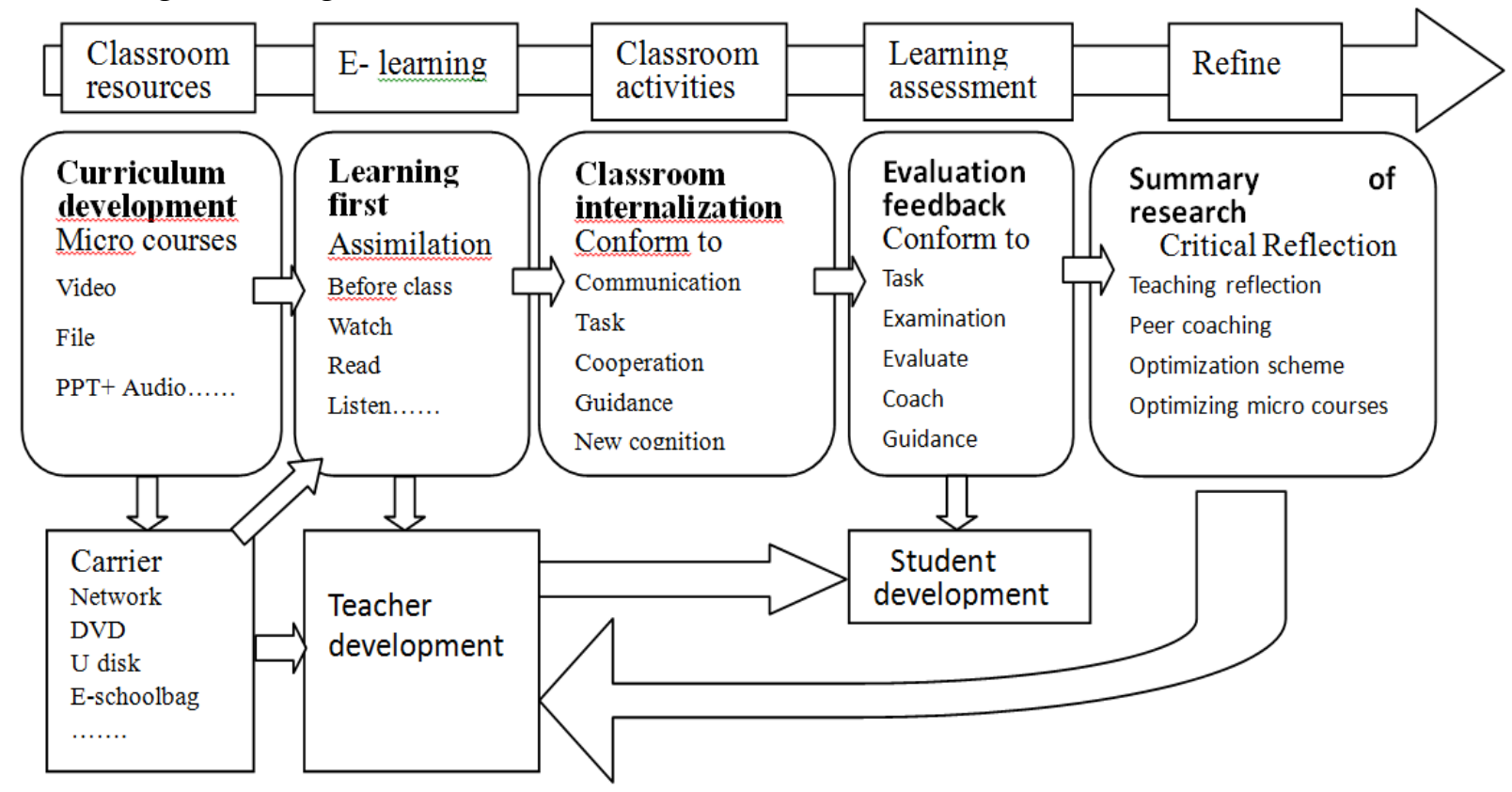

Figure 1 Logistics overturning classroom model

Flipped Classroom and Its Characteristics. With the development of the Internet plus ", students can be more convenient access to quality educational resources, through the computer and the Internet to find themselves want to get knowledge. In this way, students can complete the first two in the course of "preaching, teaching and reasoning" in class. In class, the teacher should do third things, namely, preaching, teaching, and solving[7]. Therefore, the "Internet plus" under the background of the flipped classroom to improve students' learning initiative, has a very good effect to improve the efficiency of the classroom.

First, the flipped classroom is open. The opening of the "flipped" class in the teaching of logistics mainly refers to the opening of the content of the teaching, not merely the opening of the form. The openness of logistics teaching, compared with the traditional teaching methods, the location of teachers and students change, students change from supporting roles to leading roles, while teachers change from leading roles to supporting roles, emphasizing the role of students as the main body[8]. We use the case teaching is associated with the enterprise, from the enterprise production, management and practice case, there is no ready-made answers, students must be based on the existing knowledge, play their own initiative to learn, through the "Internet plus" technology analysis, study and solve the problem, this is also the process of turning process the classroom. In the process of discussing enterprise cases, different students have different understanding of the problem, the ability and method of solving problems are different, so the solutions given are different. Students and students can provide the best solution through interaction and discussion, which will benefit students in the process.

Secondly, the classroom is interactive. The successful implementation of flipped teaching is based on the wide participation of students. In the process of teaching, the degree of student participation directly affects the quality and effect of the whole teaching[9]. Flip the purpose of 
teaching is to train students to learn the theoretical knowledge to practical problems which teachers can consciously guide, let the students learn to acquire relevant knowledge by Internet or books, after repeated use of cyber source and library resources to solve the problem, the students will master the method of autonomous learning, autonomous learning become a reality.

Implementation Conditions of Turnover Teaching in Logistics Classroom. The logistics curriculum is based on the practical curriculum, taking the students' independent learning as the main line. With the development of the Internet plus "technology, cyber source digital library, for example, $\mathrm{Mu}$ micro classes, library and other information is very rich, many logistics enterprises in the site is open to the public, you can find many logistics information relevant information on its website, in the process of learning, students can be exposed to some enterprises employees of the enterprise regulations, business processes, logistics and enterprise data in advance the rules. These network materials can not only make students acquire more knowledge, but also enable students to contact enterprises and society in advance[10]. Table 1 is the design process of logistics classroom activities.

Table 1 Logistics classroom activities design process

\begin{tabular}{|c|c|c|c|}
\hline Active link & Concrete steps & Organization form & Time allocation \\
\hline $\begin{array}{l}\text { Test feedback } \\
\text { before class }\end{array}$ & $\begin{array}{l}\text { A common error has been } \\
\text { raised against the student's } \\
\text { instructional videos; } \\
\text { Main characteristics and } \\
\text { practice methods of } \\
\text { carding logistics cases. }\end{array}$ & Teach & 8 minutes \\
\hline $\begin{array}{l}\text { Discussion and } \\
\text { exchange }\end{array}$ & $\begin{array}{l}\text { Please complete the } \\
\text { exercises after class to } \\
\text { form a team and expand } \\
\text { exchanges and mutual } \\
\text { correction method, } \\
\text { strengthen the correct } \\
\text { logistics practice. }\end{array}$ & Group discussion & 12 minutes \\
\hline $\begin{array}{l}\text { Teacher-student } \\
\text { interaction }\end{array}$ & $\begin{array}{l}\text { According to the result of } \\
\text { the discussion, the scheme } \\
\text { of logistics practice is } \\
\text { defined, and the practical } \\
\text { ability is extended from the } \\
\text { practice method. }\end{array}$ & Interactive teaching & 20 minutes \\
\hline Summary & $\begin{array}{l}\text { By expanding the study } \\
\text { and discussion, we get the } \\
\text { effective methods of } \\
\text { logistics practice and how } \\
\text { to apply it. }\end{array}$ & $\begin{array}{l}\text { Discuss the } \\
\text { interaction and come } \\
\text { to a conclusion }\end{array}$ & 5 minutes \\
\hline
\end{tabular}

The Selection of Logistics Cases in Flipped Class. In the "Internet plus" era, knowledge has become a very simple thing. Therefore, the mere introduction of knowledge is no longer popular with students. At present, we should pay attention to training students' ability to acquire knowledge, the ability to use knowledge and the ability to create knowledge. Turnover teaching not only can train students' ability to apply knowledge, but also can train students' ability to acquire knowledge. In logistics teaching, the use of flip type teaching has both conditions and significance, and the choice of logistics cases is very important[6]. In order to achieve better teaching results, the selection of logistics cases in the classroom should follow the following principles.

(1) The case must be representative

The choice of logistics in the classroom case according to the logistics theory knowledge, let students make logistics theoretical knowledge to the case, and can better solve the case in the process of theoretical knowledge, so the choice of the case must be representative.

(2) The case should be rich and vivid

In order to make students better accept the theoretical knowledge, the choice of case must be equipped with related images or pictures, students will bring to the logistics field, access to logistics equipment, see the logistics business processes, promote students to participate actively in the logistics course to make teaching achieve better results. 
(3) The case should have a clear purpose of teaching

The application of a case is to serve the purpose of teaching, so in order to ensure that students start tilting at the exact line of learning, teachers should give some hints and solutions for the case, to ensure that students have a certain way of thinking.

(4) The case should be concise and objective

Language in case to the introduction and objective problem is simple, but has certain controversial, there is a solution not, different students can use different methods give different solutions, give full play to the students' imagination and creativity.

(5) School enterprise interaction

The choice of case should be the real case of the enterprise, which is beneficial for students to understand the real situation of the enterprise. The case is more authentic and practical, and the students can contact the enterprise and society ahead of time.

\section{Implementation Points of Logistics Classroom Flipped Teaching.}

(1) Students participate more and teachers participate less

Flip type teaching pays attention to students' participation, on the one hand, it can stimulate students' thinking and thinking ability, and train students' ability to make use of knowledge, acquire knowledge and create knowledge. In this process, students are the main body and give full play to their enthusiasm. On the other hand, in the flipping classroom, the teacher's primary role is to induce students to conduct a comprehensive and profound understanding of the problem, which can not only explain, and not letting the students, but in the foundation does not interfere with the free play of the students, guide students to judge and solve problems, so as to promote the smooth progress of the classroom.

(2) Teachers should be guided and summarized

Since the implementation of the case is supported by the logistics theory, the student must be guided by the teacher to complete a complete solution. The teacher's summary and evaluation should not give the final solution of the case, but can give a high degree of summary and summary in the discussion process, and leave some doubt for the students to think.

(3) Reasonable time

The reversal teaching method is a practice process, must guarantee the time sufficiency, the time insufficiency may cause the analysis insufficiently thorough, the implementation is not thorough enough, should not achieve the anticipated result. In the process of overturning teaching, teachers should select a brief case from the classroom. For a wide range of logistics cases, in the pre class, suitable for students to arrange study and discussion, to ensure more time is to discuss cases, not to solve cases, so that more students can participate in the discussion of learning.

\section{The Promotion of Other Modern Educational Technology to Logistics Education}

"The development of Internet plus a trend which cannot be halted" technology, the application in logistics management specialty in the is like a duck, to promote the development of modern educational technology. The modern educational technology used in logistics teaching deals with the flipped classroom, as well as case teaching method, school enterprise interaction, project teaching method and game teaching method, etc.. Between the modern education technology to rely on each other, mutual penetration, interaction in logistics education, modern logistics makes education more conform to the needs of the times, in line with today's training a large number of enterprises and the society applied talents[8].

\section{Summary}

The modern educational technology, such as reversal teaching, is an effective way to improve the quality of the classroom teaching of logistics. It can improve the ability of students to learn autonomously and to create knowledge. In the process of teaching, teachers do a good job of organization and guidance, grasp the main points and purpose of the classroom, so that students are in the process of implementation of the case to obtain growth and progress. In addition, flip type 
teaching can also help students to communicate with each other through the discussion and cooperation between students, and to enhance their ability to unite and cooperate, so as to promote the integration between them.

\section{Reference}

[1] Jinlu Liu. Research on the development of e-commerce logistics of agricultural products in China[J]. Market Weekly, 2016(3).

[2] Liguo $\mathrm{Xu}$, Meimei Zhu. Research and solution of the problem of cold chain logistics providers era of fresh agricultural products[J]. Jiang Shang theory, 2016(4).

[3] Xiaoya Ma, Wu huang. "Internet plus" under the background of Guangxi characteristic agricultural products logistics development research[J]. Prices Monthly, 2017(1).

[4] Guihua Zheng, Wanlin Huang. Problems and Countermeasures of rural logistics distribution under E-commerce[J]. Economic Forum, 2016(2).

[5] Xiamei Zhao. The application of flipped class in optimizing secondary vocational logistics teaching[J]. Teacher Edition, 2015(24):264.

[6] Yanyan Zhu. Talking about the function of flipped class on the reform of teaching methods in Vocational Colleges[J]. Education, 2015(4):192.

[7] Xuemin Zheng. Analysis of flipped classroom teaching model of logistics management major in Higher Vocational Colleges[J]. Modern vocational education, 2016(12):168-169.

[8] Jun Li. Practical research on the application of flipped class in Higher Vocational Mathematics Teaching[D]. Soochow University, 2015.

[9] Minshan Zhu. Research on internal control of logistics enterprises -- Taking H logistics enterprises as an example[D]. Anhui University of Finance and Economics, 2015.

[10] Jianhua Cao. Small pallet leveraging large logistics[N]. International Business, 2017.7.20. 